\title{
Determination of Irrigation Supply Efficiency in Challenging Environment Case Study of Bal'ad District, Middle Shabelle Region in Somalia
}

\author{
Abdirashid A. Omar*, Christian Omuto, Stephen Ondieki \\ Department of Environmental and Biosystems Engineering, University of Nairobi, Nairobi, Kenya \\ Email: *rashiid.9.som@gmail.com, rashiid80@hotmail.com, cthine@gmail.com, scondieki@gmail.com
}

How to cite this paper: Omar, A.A., Omuto, C. and Ondieki, S. (2019) Determination of Irrigation Supply Efficiency in Challenging Environment Case Study of Bal'ad District, Middle Shabelle Region in Somalia. Computational Water, Energy, and Environmental Engineering, 8, 1-10.

https://doi.org/10.4236/cweee.2019.81001

Received: May 10, 2018

Accepted: January 6, 2019

Published: January 9, 2019

Copyright $\odot 2019$ by authors and Scientific Research Publishing Inc. This work is licensed under the Creative Commons Attribution International License (CC BY 4.0).

http://creativecommons.org/licenses/by/4.0/

(c) (i) Open Access

\begin{abstract}
The paper aims to determine the irrigation water supply efficiency of different irrigation methods used in the challenging environment of Bal'ad district in Somalia. Data was collected from the literature, field visits using field records and scheduled interviews, GPS coordinates and from ancillary information, such as remote sensing images and existing national maps. A comparison was done by use of secondary sources, such as academic journals using information from authorities on irrigation and water loss. Sampling was done by use of Snow balling. The results highlighted response rate for farmers being $80 \%$ while that of NGO employees is $75.76 \%$. According to the results, the main ways through which irrigation water is lost is through: evaporation; seepage through the canal bunds; overtopping the bunds; overflow losses and overwatering with the average field application efficiency of $25 \%$ and conveyance efficiency of $30 \%$. These generated a scheme irrigation efficiency of $7.5 \%$ which is poor for surface irrigation prevalent in the study area. The loss of irrigation water was found to be reduced by the following: daily supervision; proper maintenance; water allocation to farmers; good management; lining of canals; management of irrigation methods; ongoing evaluation; good land preparation; and training farmers.
\end{abstract}

\section{Keywords}

Irrigation, Water Supply, Canals, Supply Efficiency, Challenging

Environment

\section{Introduction}

Water used in irrigation is lost through evaporation from crops or soil surface or may also be lost to runoff or deed percolation [1]. 
Irrigated agriculture is the prime user of abstracted water globally, exceeding $70 \%-80 \%$ of the total in the arid and semi-arid zones [1]. It is therefore not astonishing that irrigated agriculture is alleged in those areas as the main source of water, especially in emergency drought situations. Presently, irrigated agriculture is caught between two perceptions that are contradictory; some perceive that agriculture is highly inefficient by growing "water-guzzling crops" [2]. Water for irrigation is not commonly present in the location where it is needed but it can be conveyed by use of closed or open channels. Irrigation, however, has played a large role in the increased production of cereal and export crops; and irrigation rehabilitation is a priority in Somalia [3]. There are different methods of irrigation, but surface irrigation is the most preferred type of irrigation in most parts of Somalia, including Bal'ad district [1]. The main source of irrigation water in this region is Juba and Shabele rivers which by 1980, there were more than sixty thousand hectares being irrigated and it increased steadily until 1990 when there was political instability in the country [1].

Irrigation can be defined as artificial transfer of water from the source to the field [1] while irrigation efficiency is characterized as the proportion between the water put away in the mud profundity possessed with dynamic plant roots to the water connected by the irrigation system [4]. The water is conveyed, but not equal amount reaching the destination because of different forms of losses along the way [1]. In developing countries, $70 \%-80 \%$ of water is used in agriculture [5]. Since agriculture is the major user, water loss during conveyance and distribution in irrigation networks is of great importance. Water conveyance loss consists of the following: seepage; evaporation; and operation losses into the soil from the sloping surfaces and bed of the canal. The most important of these is seepage. Evaporation loss in irrigation networks is generally not taken into consideration ([2] [6] [7] [8]). Seepage being a major loss of conveyed water for irrigation in Bala'd can be divided into two groups. The first is waste full use of water, which is obtained at a high cost and with difficulty from various sources. The second is the problem of drainage, salinity, and alkalinity [9].

This paper tends to find the supply efficiency of the irrigation system and major contributors of water loss in the canals in Bal'ad and as well proposing some of the quantitative methods of water management. Since the conveyance system can be very broad, this paper only looks at the water loss in canals only. Conveyance efficiency has been affected by negligence and political instability and this leads to loss of unknown amount of water in canals. In order to achieve sustainable irrigation, then conveyance efficiency is to be addressed.

\subsection{Major Irrigation Water Losses in Somalia}

\subsubsection{Surface Method}

Surface irrigation is the most common method of water application to fields in Bal'ad district. A number of surface irrigation methods are used but all have a number of limitations including: the depth of water application is determined by the rate of soil infiltration [1]. In surface irrigation, the designs are improved its 
management and land preparation; new techniques are now used to control the depth of application and uniform water distribution across the field. Nevertheless, the overcoming of uneven soil water intake rates is impossible leading to uneven infiltration of water within the field [1]. The research on surface irrigation further says that, the application can be efficient in uniform soils of moderate to low infiltration and otherwise in heterogeneous and light textured soils [1]. It is therefore important to reduce the above losses in the conveyance canals.

\subsubsection{Overwatering}

Over-watering is likely the most critical reason for water loss in any irrigation system. Regardless of how well the system is outlined, if more water is connected than can be usefully used by the yield, effectiveness will endure [4]. In this way, legitimate irrigation booking is critical if high efficiencies are to be accomplished. Different types of conceivable water losses are particular to the kind of irrigation system used. Immediate dispersal from the wet soil surface, overflow losses, and leakage losses from water conveyance trench besides overwatering. Overflow losses can be practically disposed of with return stream systems that catch the spillover water and direct it back to the starting field, or to different fields. The measure of drainage loss from unlined trench will rely on upon soil qualities and the degree of the trench system yet may extend from $10 \%$ to $15 \%$ of the supplied water. Leakage losses are wiped out with lined waterways or channel dissemination systems [4].

A percentage of the water "lost" to wind float and dispersal from the sprinkler shower is not really lost, since it substitutes for crop evaporation. Net losses for this situation may be as low as $2 \%-3 \%$, to as high as $15 \%-20 \%$ under amazing unfavorable conditions. All around kept up sprinkler systems ought to have hole and seepage losses underneath $1 \%$, yet ineffectively oversaw systems have demonstrated losses of close to $10 \%$.

If stream system losses ought to be low. In spite of the fact that a generally little parcel of the mud surface is wetted, the irrigation recurrence is high, so there will be some loss because of dispersal from wet soil. With great administration, losses because of holes, system waste, and flushing of channels and horizontal lines ought not to surpass $1 \%$.

\section{Materials and Methods}

\subsection{Data Requisition}

This study used both secondary and primary data. The data collected was by use of the following: Literature review; GPS machines; use of questionnaires/ management reports; and scheduled interviews.

\subsection{Data Acquisition}

After selection of the sample canals in Bala'd district, the canal course was assessed to identify current status of the canals. Relevant measurements were taken by calculating Area, $\left(\mathrm{m}^{2}\right)$ of the intake, middle points of the canal and measure 
flow rate and outlet points of the canals and mean velocity of both points and then subtracted in order to find the loss as a ratio of water diverted to the canal divide by water delivered. Using questionnaire and management reports and design documents (literature review), the researcher computed the conveyance efficiency of the canals. Canal efficiency was calculated as presented by Equations (1) and (2)

Using inflow-outflow equation where:

Water losses percentage (\%) = amount of water diverted minus amount of water delivered to the field divided by amount of water diverted multiplied 100

$$
(Q i-Q 0) /(Q i \times 100)
$$

where: $Q i$ is water input $\left(\mathrm{m}^{3} / \mathrm{s}\right)$ and $Q 0$ is water output $\left(\mathrm{m}^{3} / \mathrm{s}\right)$.

$$
\begin{aligned}
& \text { Losses }(\% \text { per } 100 \mathrm{~m}) \\
& =[(Q i-Q 0) / Q i \times 100] \times(100 / L)=(\% \text { losses } / \text { total length }) \times 100
\end{aligned}
$$

where: $L$ is the length of the canal.

\section{Research Design and Sampling Method}

The research was on determining irrigation water supply losses in the major irrigation canal conveyance water loss in Bala'd district. The research was no experimental. The type of research was descriptive research by use of survey and specifically using questionnaire and interview schedule. Descriptive studies are usually based on previous understanding of a research problem [10]. Moreover, descriptive survey helps to identify and describe the variables that exist in certain situations and to explain the correlation between those variables thus helping to portray a picture of a certain phenomenon. Examples of descriptive statistics are the measures of central tendency like mode, median, range, mean variance, standard deviation, measures of dispersion and frequency [11].

The study has adopted the snowballing method. Snowballing is a non-probability sampling method used by researchers to identify potential respondents in studies where locating participants is hard. Researchers often use this approach if the sample for their study is either rare or limited to a small subset of the entire population. The sampling works in the same way as chain referral. Once the researcher has observed the first subject, he goes ahead to ask the participant to help in identifying other people having a similar trait of interest. It is like asking your initial participants to nominate other individuals with similar traits. The researcher observes the nominated subject and goes on in the same way until a significant number of participants have been obtained [11]. Figure 1 below shows a schematic representation of snow balling.

\section{Data Analysis}

The questionnaires collected was analysed and sampled by use of snow balling. The difference in the data was compared by use of secondary data in the journals. 


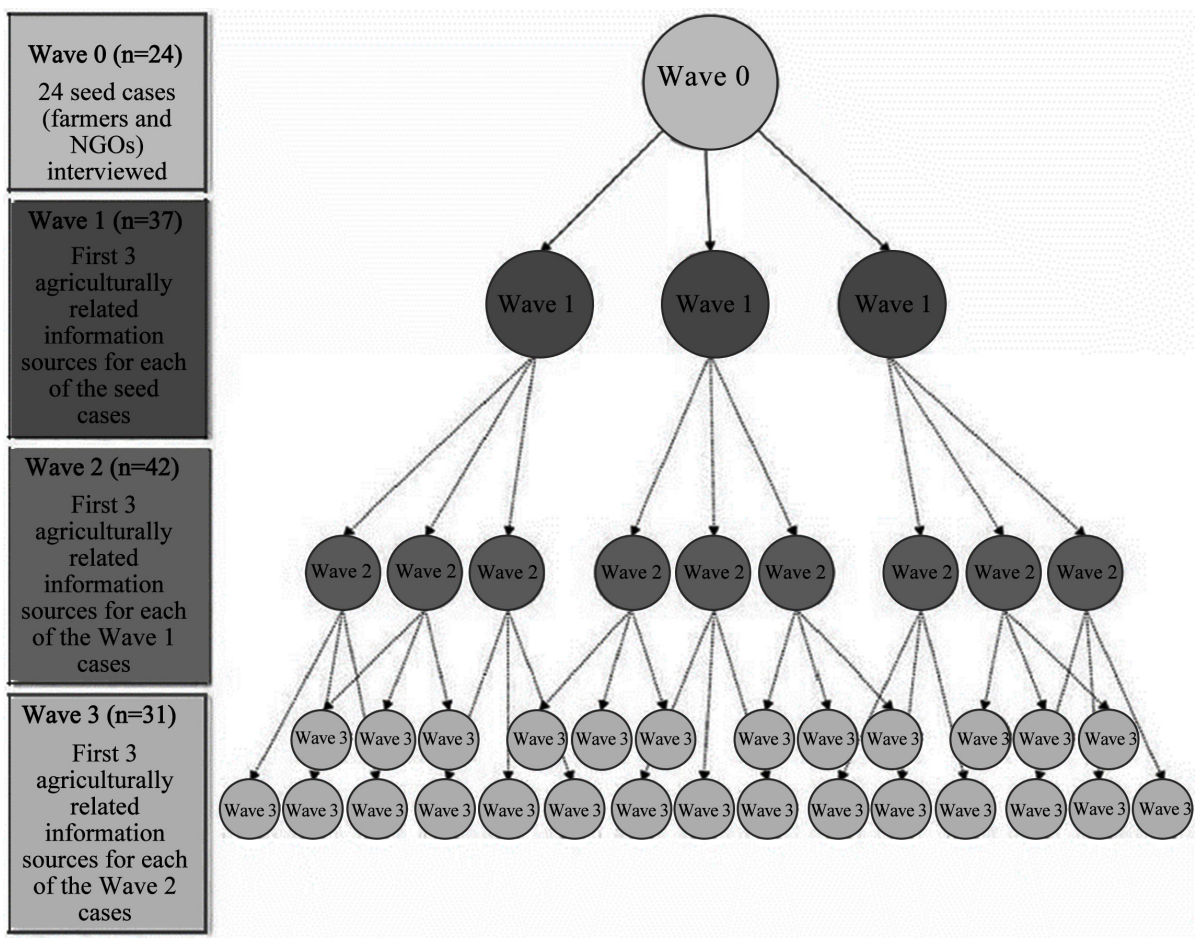

Figure 1. Snow balling method.

\section{Results}

The two respondent groups and the target number to respondent in each group are: 20 farmers using irrigation; and 33 NGO employees. Out of these, 16 farmers and $25 \mathrm{NGO}$ employees responded. Therefore, the response rate for farmers was $80 \%$ and that of NGO employees was $75.76 \%$. Figure 2 below shows percentage respondent of farmers and NGO group.

The conveyance system is through open system, which is the use of canals. The water loss is through the following methods in Bala'd district: Evaporation from water surface; Seepage through canal bunds; Bund breaks; Deep percolation to the soil layers beneath the canals; Runoff through the drain; Overtopping the bunds; and Rat holes in canal bunds. From the response in each sampled group, it was established that water loss frequency and percentage in the conveyance system is as summarized in Figure 3 below.

The water loss is majorly through evaporation and seepage in canals as shown in Figure 4. Others are overtopping the buds, runoff through drains and rat holes in canals bunds. It was not easy to estimate the water loss through bund breaks and deep percolation by the respondents.

The respondents argued that the loss through evaporation and seepage is because of the long canals of more than $2000 \mathrm{~m}$ and other are ranging between 200 $\mathrm{m}$ and $2000 \mathrm{~m}$. The reason for overtopping is the sediment settlement since the canals are maintained or cleaned yearly. This is a very long time for the maintenance of the canals, which has water carrying large sediments hence reducing the volume of the canals. 


\section{Percentage Responce in each group}

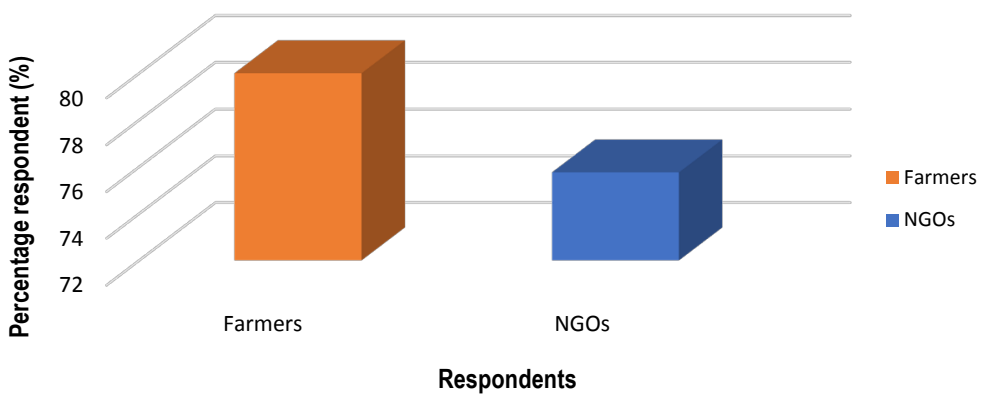

Figure 2. Percentage respondent in each sampled group.

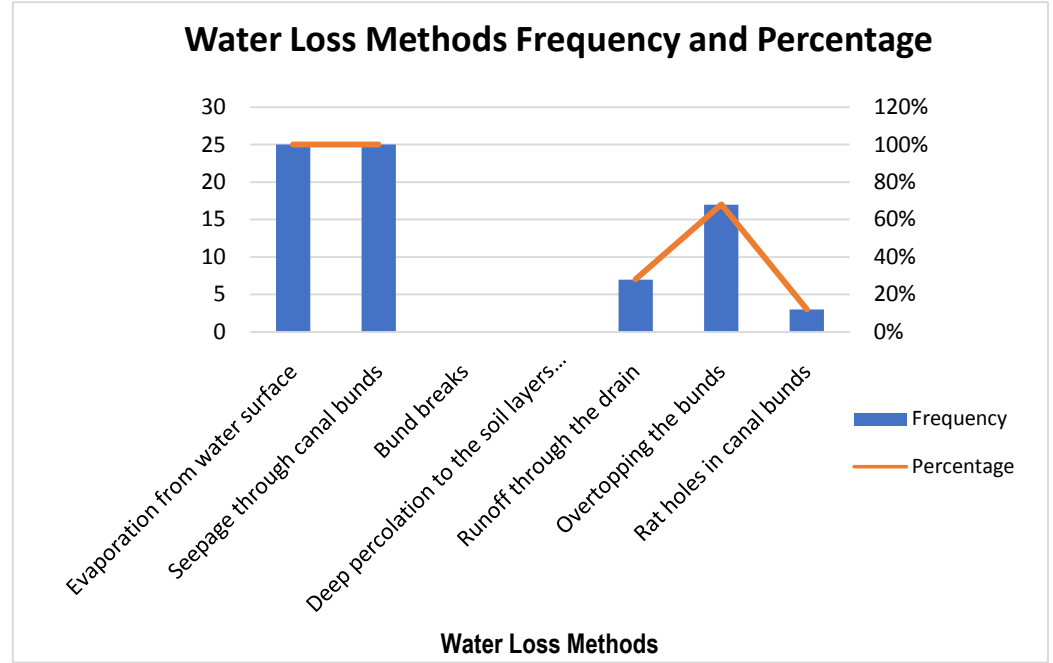

Figure 3. Water loss methods in Bala'd district.

\section{Figure 5: Irrigation Type Used by the Farmers}

$\square$ surface irrigation $\square$ basin irrigation $\square$ border irrigation $\square$ furrow irrigation

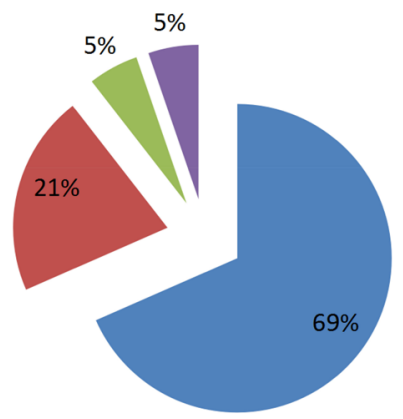

Figure 4. Types of irrigation systems used. 


\section{Ways of Preventing Irrigation Water Loss in Canals and Farm Lands}

The respondents gave the following solutions for preventing water losses: capacity building of the farmers and management; good land preparation; continuous maintenance of the canals; lining of the canals; daily supervision; continuous assessment and evaluation; and good management of irrigation methods.

Lining of canals is one of the ways of preventing water loss in a canal but according to Wachyan and Rushton in 1987 [12] in the study of water loss in an irrigation canals, they found out that even though the canal is lined $99 \%$ it reduces seepage by only $30 \%-40 \%$. This shows that even if the canal is lined some water is still lost by seepage and further control measures should be used.

They further argued that, seepage loss from canals is governed by hydraulic conductivity of the subsoil, canal geometry, and potential difference between the canal and the aquifer underneath which in turn depends on the initial and boundary conditions. Seepage losses are also influenced by clogging of the canal surfaces depending on the suspended sediment content of the water and on the grain size distribution of the suspended sediment particles. The clogging process can decrease the seepage discharge both through bottom and slopes. Thus, the seepage loss can change within time and under certain conditions it can diminish. Therefore, the seepage loss can be higher at the beginning of the canal operation and can be lower after a few years of operation.

The evaporation loss of water in the canals as one of the main cause of water loss depends on the supply of energy to provide the latent heat of vaporization and the ability to transport the vapour away from the evaporating surface. This in turn depends on the wind velocity over the surface and the specific humidity gradient in the air above the water surface [13]. The water losses in Bada'd is affected by the type of irrigation systems used. Figure 4 shows the types of irrigation system used. The high-water loss is experienced because of the use of surface irrigation and the water lost is majorly on evaporation.

The farmers gave the following response according to their experiences: supervision to know when and where water is lost; proper maintenance; water allocation to each farmer; good management and good preparation of land; lining of the canals; and training of farmers on proper use of irrigation water. On the other hand, field measurements on the canals were taken, especially intake dimensions, middle and end tails to know the amount of water that was diverted and amount of water that reached the secondary canals at the current canal status and results are presented in Table 1 below.

\section{Discussion and Conclusion}

\subsection{Discussion}

The study targeted irrigation-based farmers and NGO employees in Bal'ad. The response rate for farmers was $80 \%$ while that of NGO employees was $75.76 \%$. According to the results, the main ways through which irrigation water is lost 
Table 1. Volume of water on the Canal Intake, Middle and Outlet.

\begin{tabular}{|c|c|c|c|c|c|}
\hline$S / N$ & $\begin{array}{c}\mathrm{A} \\
\text { (intake) }\end{array}$ & $\begin{array}{c}\text { B } \\
\text { (Middle) }\end{array}$ & $\begin{array}{c}\mathrm{C} \\
\text { (outlet) }\end{array}$ & $\begin{array}{c}\text { A-B loss } \% \text { and loss } \% \text { for } \\
\text { each } 100 \mathrm{~m}\end{array}$ & $\begin{array}{c}\text { B-C loss } \% \text { and } 100 \mathrm{~m} \\
\text { lose } \% \text { each }\end{array}$ \\
\hline $\begin{array}{l}\text { Canal.1 } \\
(1.8 \mathrm{~km})\end{array}$ & $0.253 \mathrm{~m}^{3} / \mathrm{s}$ & $0.189 \mathrm{~m}^{3} / \mathrm{s}$ & $0.149 \mathrm{~m}^{3} / \mathrm{s}$ & $\begin{array}{c}25.3 \% \text {, and each } 100 \mathrm{~m} \\
\text { lose } \%=2.811\end{array}$ & $\begin{array}{c}21.16 \% \text { and each } 100 \mathrm{~m} \\
\text { lose }=2.35 \%\end{array}$ \\
\hline $\begin{array}{c}\text { Canal. } 2 \\
(2 \mathrm{~km})\end{array}$ & $0.1037 \mathrm{~m}^{3} / \mathrm{s}$ & $\begin{array}{c}0.0855 \\
\mathrm{~m}^{3} / \mathrm{s}\end{array}$ & $0.0783 \mathrm{~m}^{3} / \mathrm{s}$ & $\begin{array}{c}17.55 \% \text { and each } 100 \mathrm{~m} \\
\text { Lose }=1.755 \%\end{array}$ & $\begin{array}{c}8.42 \% \text { and lose } \% \text { each } \\
100 \mathrm{~m} 0.842 \%\end{array}$ \\
\hline $\begin{array}{l}\text { Canal. } 3 \\
(3.8 \mathrm{~km})\end{array}$ & $0.1047 \mathrm{~m}^{3} / \mathrm{s}$ & $0.082 \mathrm{~m}^{3} / \mathrm{s}$ & $0.067 \mathrm{~m}^{3} / \mathrm{s}$ & $\begin{array}{c}21.16 \% \text { And each } 100 \mathrm{~m} \\
\text { lose } \%=1.12736\end{array}$ & $\begin{array}{c}18.3 \% \text {. and each } 100 \mathrm{~m} \\
\text { lose }=95 \%\end{array}$ \\
\hline $\begin{array}{c}\text { Canal. } 4 \\
(2 \mathrm{~km})\end{array}$ & $0.1687 \mathrm{~m}^{3} / \mathrm{s}$ & $0.153 \mathrm{~m}^{3} / \mathrm{s}$ & $0.135 \mathrm{~m}^{3} / \mathrm{s}$ & $\begin{array}{c}9.3 \% \text { and each } 100 \mathrm{~m} \text { lose } \\
\quad=0.93 \%\end{array}$ & $\begin{array}{c}11.76 \% \text { and each } 100 \mathrm{~m} \\
\text { lose }=1.176 \% .\end{array}$ \\
\hline $\begin{array}{l}\text { Canal. } 5 \\
(2 \mathrm{~km})\end{array}$ & $0.165 \mathrm{~m}^{3} / \mathrm{s}$ & $0.136 \mathrm{~m}^{3} / \mathrm{s}$ & $0.133 \mathrm{~m}^{3} / \mathrm{s}$ & $\begin{array}{c}17.57 \% \text { and each } 100 \mathrm{~m} \\
\text { lose }=1.757 \%\end{array}$ & $\begin{array}{c}2.2 \% \text {, and each } 100 \mathrm{~m} \\
\text { lose } \%=0.22 \%\end{array}$ \\
\hline $\begin{array}{l}\text { Canal. } 6 \\
(2 \mathrm{~km})\end{array}$ & $0.185 \mathrm{~m}^{3} / \mathrm{s}$ & $0.180 \mathrm{~m}^{3} / \mathrm{s}$ & $\begin{array}{c}0.11475 \\
\mathrm{~m}^{3} / \mathrm{s}\end{array}$ & $\begin{array}{c}2.7 \% \text {, and each } 100 \mathrm{~m} \text { lose } \\
=0.27 \%\end{array}$ & $\begin{array}{c}36.25 \% \text { and each } 100 \mathrm{~m} \\
\text { lose }=3.625 \%\end{array}$ \\
\hline $\begin{array}{l}\text { Canal. } 7 \\
(2 \mathrm{~km})\end{array}$ & $0.1181 \mathrm{~m}^{3} / \mathrm{s}$ & $\begin{array}{c}0.0936 \\
\mathrm{~m}^{3} / \mathrm{s}\end{array}$ & $0.0765 \mathrm{~m}^{3} / \mathrm{s}$ & $\begin{array}{c}20.75 \text { and each } 100 \mathrm{~m} \text { lose } \\
=2.0 \%\end{array}$ & $\begin{array}{c}18.27 \% \text {, and each } 100 \mathrm{~m} \\
\text { lose }=1.827 \%\end{array}$ \\
\hline $\begin{array}{l}\text { Canal. } 8 \\
(3 \mathrm{~km})\end{array}$ & $0.189 \mathrm{~m}^{3} / \mathrm{s}$ & $0.175 \mathrm{~m}^{3} / \mathrm{s}$ & $0.166 \mathrm{~m}^{3} / \mathrm{s}$ & $\begin{array}{c}7.4 \% \text { and each } 100 \mathrm{~m} \text { lose } \\
=4.9 \%\end{array}$ & $\begin{array}{c}5.14 \% \text { and each } 100 \mathrm{~m} \\
\text { lose } \%=3.42 \%\end{array}$ \\
\hline $\begin{array}{l}\text { Canal } 9 \\
(4.2 \mathrm{~km})\end{array}$ & $0.1113 \mathrm{~m}^{3} / \mathrm{s}$ & $\begin{array}{c}0.0855 \\
\mathrm{~m}^{3} / \mathrm{s}\end{array}$ & $0.0689 \mathrm{~m}^{3} / \mathrm{s}$ & $\begin{array}{c}24.7 \% \text {, and each } 100 \mathrm{~m} \\
\text { lose }=1.175 \%\end{array}$ & $\begin{array}{c}19.4 \% \text {, and each } 100 \mathrm{~m} \\
\text { lose }=0.92 \%\end{array}$ \\
\hline
\end{tabular}

include evaporation, seepage through the canal bunds, overtopping the bunds, overflow losses, and overwatering. The average field application efficiency was 25 percent while the conveyance efficiency was 30 percent. This generated a scheme irrigation efficiency of 7.5 percent which is poor for surface irrigation prevalent in the study area.

In terms of preventing the loss of irrigation water, the respondents mainly suggested daily supervision, proper maintenance, water allocation to farmers, good management, lining of canals, management of irrigation methods, ongoing evaluation, good land preparation, and training farmers.

Most farmers from the study area have been using irrigation for over years and a greater percentage of them ( 50 percent) own over 10 acres of farming land implying that irrigation farming is done on a large scale in Bal'ad. Most farmers have their farming lands over 1000 meters away from the irrigation source. Hence, more water is lost because of the long distance mainly through seepage and runoffs. Besides, most farmers use surface irrigation which results in more water loss through evaporation, runoffs and percolation.

\subsection{Conclusion}

Irrigation is not efficient owing to different ways through which water is lost both in the canals and farming lands. The main ways of water loss around the canals include seepage through the canal bunds, rat holes around the canals, and run offs. In the farming lands, water is lost through evaporation from the sur- 
face, overwatering and percolation.

Both farmers and those managing irrigation canals know the venues of water loss and are willing to take the necessary measures to prevent further losses. To improve the efficiency of irrigation, farmers ought to be more disciplined in the amount and duration of irrigation. On the other hand, the management has the responsibility of creating a maintenance schedule for canals and an irrigation schedule.

\section{Recommendation}

1) To achieve adequate data on water conveyance efficiency, a larger sample of data e.g. $(30 \times 30)$ should be used.

2) Further research should be done on the lining methods for canals to achieve more than $70 \%$ of water retention.

3) A model for assessing water conveyance should be developed or adopted to allow efficient monitoring of water throughout the system.

\section{Acknowledgements}

I would like to acknowledge Bal'ad district commissioner for his aid in provision of security during my data collection in Bal'ad, organizing for farmers who took the questionnaires and interviews. He also made it possible for me to assess the topographical map of the site.

My research could not have come through if there were no farmers to take questionnaires and interviews on the conveyance system in Bal'ad district for that I acknowledge the farmers who accepted to answer my questionnaires.

\section{Conflicts of Interest}

The authors declare no conflicts of interest regarding the publication of this paper.

\section{References}

[1] Fereres, E., Goldhamer, D.A. and Parsons, L.R. (2013) Food and Agriculture Organisation (FAO). The State of the World's Land and Water Resources for Food and Agriculture.

[2] Postel, S.L., Daily, G.C. and Ehrlich, P.R. (1997) Human Appropriation of Renewable Freshwater. Science, 271, 785-788. https://doi.org/10.1126/science.271.5250.785

[3] Biswas, A.K., Masakhalia, Y.F.O., Odero-Ogwel, L.A. and Pallangyo, E.P. (1987) Land Use and Farming Systems in the Horn of Africa. Land Use Policy, 4, 419-443. https://doi.org/10.1016/0264-8377(87)90064-0

[4] Siebert, S., Burke, J., Faures, J.M., Frenken, K., Hoogeveen, J., Döll, P. and Portmann, F.T. (2010) Groundwater Use for Irrigation-A Global Inventory. Hydrology and Earth System Sciences, 14, 1863-1880. https://doi.org/10.5194/hess-14-1863-2010

[5] Hamdy, A., Lacirignola, C. and Trisorio-Liuzzi, G. (2000) Water Saving and Increasing Water Productivity: Challenges and Options. Advanced Short Course on Water Saving in Irrigated Agriculture, 2-16 April, Cairo. 
[6] Xie, M., Küffner, U. and Le Moigne, G. (1993) Using Water Efficiently: Technological Options. World Bank Technical Paper Number 205, Washington DC, USA.

[7] Çevik, B. and Tekinel, O. (1995) Sulama fiebekeleri ve flletme Yöntemleri. Ç.Ü. Ziraat Fakültesi Ders Kitabı No: 81, Adana.

[8] ANCID. (2000) Open Channel Seepage and Control-Literature Review of Channel Seepage Identification and Measurement. Vol. 1.1, Australian National Committee on Irrigation and Drainage (ANCID), Victoria, Australia.

[9] Balaban, A. (1970) Sulama fiebekelerinde Kanal ve Tarla Arkları Sizma Kayıpları Üzerinde Bir Arafltırma. Ankara Üniversitesi, Ziraat Fakültesi Yayınları, No. 455, Ankara.

[10] Zikmund, W.G. (2003) Business Research Methods. 7th Edition, Thomson/South-Western.

[11] Cooper, D. and Schindler, P. (2003) Monitoring and Evaluation in Business. Business Research Method. 7th Edition, Vol. 6, McGraw-Hill, New York.

[12] Wachyan, E. and Rushton K.R. (1987) Water Losses from Irrigation Canals. Journal of Hydrology, 92, 275-288. https://doi.org/10.1016/0022-1694(87)90018-7

[13] Chahar, B.R. (2000) Optimal Design of Channel Sections Considering Seepage and Evaporation Losses. PhD Thesis Submitted to Department of Civil Engineering, University of Roorkee, Roorkee, India. 